\title{
Culture and mathematics learning: Identifying students' mathematics connection
}

\author{
Al Kusaeri, Habib Husnial Pardi, Abdul Quddus ${ }^{1}$
}

Abstrak: Koneksi matematika mendukung siswa menemukan berbagai kemungkinan strategi dalam penyelesaian masalah. Produk budaya memungkinkan dapat dijadikan objek matematika dalam pembelajaran. Artikel ini merupakan bagian dari penelitian yang merancang desain pembelajaran berbasis budaya lokal yang bertujuan mengidentifikasi kemampuan koneksi matematika siswa. Data dikumpulkan melalui tes yang diberikan kepada 341 siswa dan wawancara tidak terstruktur terhadap 9 siswa yang dipilih berdasarkan penyelesaian tes sesuai proses matematisasi. Analisis data diawali dengan klasifikasi jawaban siswa berdasarkan tahapan matematisasi, identifikasi kemampuan koneksi matematika sesuai tahapan matematisasi, analisis kemampuan koneksi matematis, dan penarikan simpulan terkait kemampuan koneksi matematika serta kendala yang ditemukan. Hasil penelitian menunjukkan bahwa kemampuan koneksi matematika siswa meliputi tiga kategori yaitu koneksi pemahaman, koneksi representasi, dan koneksi justifikasi. Siswa dengan kemampuan koneksi justifikasi bisa menyelesaikan masalah matematika sesuai tahapan matematisasi, dari identifikasi objek matematika sampai matematika formal. Sementara itu, siswa yang memiliki kemampuan koneksi pemahaman dan representasi menyelesaikan masalah matematika masing-masing sampai pada tahap model kongkret dan model formal. Hasil penelitian menunjukkan bahwa pembelajaran berbasis budaya memberikan ruang untuk memahami kemampuan koneksi matematika siswa. Penelitian lebih lanjut dibutuhkan untuk menunjukkan pembelajaran berbasis budaya bisa digunakan untuk mengembangkan kemampuan koneksi matematika siswa.

\section{Kata Kunci: Pembelajaran matematika, Budaya, Koneksi matematika}

\begin{abstract}
Mathematics connection support students finding various possible strategies in problemsolving. Cultural products can be used as mathematical objects in learning. This article, part of a study that designed culture-based learning, aims to identify students' mathematics connection. Data was collected through a test given to 341 students and unstructured interviews of nine students selected based on the completion of the test, which fulfills mathematization steps. Data analysis began by classifying students' answers based on mathematization, identifying mathematics connection of students according to mathematization, analyzing students' mathematics connection, and drawing conclusions about mathematics connection and the constraints found. The results showed that students' mathematics connections include three categories, namely understanding connection, representation connection, and justification connection. Students with justification connection solved mathematical problems according to mathematization steps, from the identification of mathematical objects to formal mathematics.

Meanwhile, students with understanding and representation connection solved their respective mathematical problems up to the concrete and formal stages. The findings reveal that culture-based mathematics learning provides space to understand students' mathematics connection. Further research is required to prove that it can be used to develop students' mathematics connection.
\end{abstract}

Keywords: Mathematics learning, Culture, Mathematics connection

\footnotetext{
${ }^{1}$ Universitas Islam Negeri (UIN) Mataram, Jln. Gajah Mada 100, Mataram, Indonesia, alkusaeri@uinmataram.ac.id 


\section{A. Introduction}

Mathematics connection is one of the standards in mathematics learning proposed by NCTM (2000) along with problem-solving, reasoning and proof, communication, and representation. Mathematics connection does exist since mathematics is not separate topics, but it is a unified whole. Besides, mathematics cannot be separated from other scientific disciplines and problems that occur in everyday life. Therefore, mathematics connection is needed; thus, students do not need to remember too many separate concepts or procedures (NCTM, 2000). Mathematics connection is also required to solve problems (Hodgson, 1995) and develop students' mathematical understanding (Hiebert \& Carpenter, 1992). If students can construct and apply their knowledge in solving problems in the surrounding environment, then mathematics learning will be more meaningful (Johnson, 2010).

Lappan, Fey, Fitsgerald, Friel, and Philips (2002) explicated that mathematics connection is learning activities which aim to enable students to define the process of solving a problem, situation, and mathematical idea related to each other into a mathematical model. Besides, students are also expected to apply the acquired knowledge to solve one problem with another. Conceptually, mathematics connection by Coxford (1995) is defined as ideas or mathematical processes used to find relationships between mathematical topics in different situations. The connection process is categorized into three activities, i.e., unifying themes, mathematical processes, and mathematical connectors. Unifying themes is a grouping of ideas or concepts contained in different mathematics topics. Understanding the themes or topics is important for students to find important ideas or information in mathematical problems and make connections (NCTM, 2000). Mathematical processes include the activities of representation, application, and problem-solving along with the reasoning and the proof. Mathematical connectors are mathematical ideas that will be discovered or demonstrated in the connection process (Coxford, 1995).

Mathematics connection can be defined as a relationship between mathematical ideas linked or grouped with other mathematical ideas (Businskas, 2008; Singletary, 2012) and the relationship between mathematical concepts with others concepts (Singletary, 2012). Mathematical ideas or concepts by Skemp (1987) are divided into primary concepts that originate from experiences or situations in the real world and secondary concepts which are part of other concepts. Mathematical ideas can be presented in different forms; for example, the concept of straight lines can be shown in the form of equations and graphs (Hodgson, 1995). The ability to show different forms of one particular mathematical concept is not an easy activity to do for students. For that reason, mathematics connection as the mathematical processes (Coxford, 1995) requires an understanding of the main ideas of a problem, the ability to show different forms of concepts, and arguments in proving the truth of mathematical processes.

Suominen (2015) grouped mathematics connection into the connection of understanding, the connection of equivalent representations, and connection of justification procedures. An understanding connection is the ability to identify information contained in a problem or situation. The ability is needed to identify the concepts and processes to solve the problem. The equivalent representation connection is a connection that is built based on the concept represented in different ways or forms but has the same value. Justification procedures connection is developed through the ability of students when checking or evaluating the correctness of answers to the concepts and procedures used. 
The idea of mathematics connection itself has long been researched in developing students' understanding of mathematical concepts as carried out by Brownell and Chazal (1935), although they are still limited to mathematical connections in arithmetic problems. Menanti, Sinaga, and Hasratuddin (2018) found that Realistics Mathematics Education can improve students' mathematical connection. It is because of the problems presented relate to students' daily experiences; thus, the problem-solving process can be more easily done by students. Rohendi and Dulpaja (2013) implemented the Connection Mathematics Project (CMP) to develop students' mathematics connection. The results showed that students' mathematics connection using CMP was better than conventional learning measured by the ability to find and solve the problems. Haji, Abdullah, Maizora, and Yumiati (2017) developed students' mathematics connection through outdoor learning. It was found that the mathematics connection of students using outdoor learning increased significantly compared to conventional learning. The relationship between mathematics connection and mathematics learning outcomes is strengthened by the findings of Ndiung and Nendi (2017). Meanwhile, the current study was conducted to identify students' mathematics connections through the implementation of Sasak culture-based mathematics learning.

The development of mathematics connection can be done with learning that utilizes contextual problems. Jaisook, Chitmongko, and Thongthew (2013) found that the ability to solve problems, communication, and mathematics connections can be improved through mathematics learning, which relates to real life. Developing students' mathematics connection through problems found in the real world is certainly not easy. Arthur, Asiedu-Addo, and Assuah (2017) found that motivation and mathematics connections with real problems owned by the teacher as well as adequate learning facilities (devices) will also directly influence the development of students' mathematics connection.

Culture-based mathematics learning is known as ethnomathematics. Mathematics, as part of cultural products developed through daily activities (Ernest, 1991), must be able to be utilized in developing students' understanding of mathematical objects into mathematical forms. Ethnomathematics is mathematics applied by certain cultural groups to balance the impression of teaching mathematics in schools that are too formal (Hiebert \& Capenter, 1992). Therefore, learning mathematics needs to provide content or bridge between mathematics in the everyday world based on local culture and school mathematics.

Unodiaku (2013) showed that the use of cultural products as a source of learning improves students' abilities in mathematical problem-solving. Simple game, namely Husa, can be used as a strategy in learning mathematics. Various cultural products cannot be influenced by systems that come from outside because they exist together with members of the local community (Yusuf, Aisha, \& Saidu, 2010). The process of finding and identifying mathematical objects through cultural objects will provide convenience in understanding mathematics, chiefly if the class consists of students with a variety of cultural backgrounds (Katsap \& Fredrick, 2008). Sharp and Stevens (2007) utilized African Drumming, the rhythm of African songs, to explain algebraic material. Zulu culture called Beadwork and Basketery can be used as a medium in developing mathematical knowledge while at the same time broadening the value of Zulu culture in students (Chahine \& Kinuthia, 2013). However, learning mathematics based on culture is not an activity that can be done easily because certain local cultural forms are very complex and allow it to be used in developing various mathematical objects and concepts.

The findings on mathematics and culture (Unodiaku, 2013; Sharp \& Stevens, 2007; Chahine $\&$ Kinuthia, 2013) showed that learning mathematics associated with local culture yield positive 
results in supporting students' understanding of mathematical concepts even though they still focus on cultural products as a medium for learning mathematics. While in this research, the cultural product is not only a media but as an object in constructing and connecting representations of one mathematical concept in different forms for problem-solving.

Mathematics connection is needed by students to develop understanding and problemsolving in mathematics (Hiebert \& Carpenter, 1992; Hodgson, 1995). To support the mathematical connections, mathematics learning which employs contextual problems can be employed (Jaisook et al., 2013; Menanti et al., 2018). Mathematics is a part of cultural products developed through daily activities (Ernest, 1991). Meanwhile, ethnomathematics supports students learning mathematics (Unodiaku, 2013; Sharp \& Stevens, 2007; Chahine \& Kinuthia, 2013). In this case, culture-based learning has the potential to develop students' mathematics connection. The current study aimed to identify students' mathematics connection through mathematics learning, which integrates Sasak culture ${ }^{2}$. Students' mathematics connection is identified through the results of problem-solving referring to the mathematization (Boswinkel \& Moerlands, 2003; Webb, Boswingkel, \& Dekker, 2008) and three categories of mathematics connection (Suominen, 2015). The indicators are set because problem-solving that refers to mathematization requires understanding, the ability to modify the form of mathematical objects, and proof on the results of problem-solving in the form of representations that are easily understood by students.

\section{B. Methods}

This study adopted a descriptive qualitative approach to identify students' mathematics connection after participating in Sasak culture-based learning. Sasak culture-based mathematics learning was carried out referring to the developed syntax, namely: (1) apperception of learning by creating positive perceptions of students about mathematics and upholding the attitudes socalled tindih and solah $^{3}$; (2) presents forms of cultural products and information on problemsolving steps by motivating and supporting students to develop a problem-solving plan based on the principle of briuk tinjal ${ }^{4}$; (3) describe and develop students' work by giving them the opportunity to present their results using base krame ${ }^{5}$; and (4) analyze and evaluate students' understanding of solving problems.

The subjects in this study were 341 four graders. The data of students' mathematics connection were obtained through two numbers of essay tests on fractions. The problem used was Determine and show the results from (1) $2-1 / 4$ and (2) $2+2 / 3$ ! Identifying students' mathematics connection required a complex picture, and analysis of information carried out through natural processes or situations (Cresswell, 2015). For this reason, a test was carried out to obtain information on students' mathematical connection by answering the questions for 20 minutes. It was to determine mathematics connection through the mathematization, namely: identification of mathematical objects, concrete models (form manipulation), formal models, and formal mathematics (Boswinkel et al., 2003; Webb et al., 2008). The identification of mathematical objects was examined through the ability of students to determine the focus of the

\footnotetext{
${ }^{2}$ Sasak culture is the culture of Lombok people who live in the West Nusa Tenggara province. The province also has two other cultures, namely Samawa and Mbojo.

${ }^{3}$ Solah means the values of goodness to preserve the quality and identity as a part of the society

${ }^{4}$ The attitudes which uphold the togetherness to achieve a consensus and action

${ }^{5}$ A very polite way in interaction and communication
} 
objects of cultural product used for form manipulation. The stage of the concrete model was measured through the suitability of the initial representations (students' drawings) with the mathematical concepts in the problem. The stage of the formal model was measured by the suitability of the representations of different numbers in the problem. The formal stage of mathematics was measured by the suitability of the representations to prove the correctness of problem-solving.

Based on the results of the test, the unstructured interview was conducted on nine students selected on the basis of their ability to solve the problems following the steps of mathematization. It aimed to get information about the constraints the students have concerning mathematics connections after participating in Sasak culture-based mathematics learning. The interview was recorded using a voice recorder. The examples of the questions asked in the interview were: Can you represent the mathematical form of cultural products in the test? What is the difficulty in determining the focus of the cultural object as a mathematical form? Can the form of cultural products represent fractions? And what are the obstacles found at each stage of the mathematization being undertaken?

Data analysis followed the steps of data reduction, data presentation, and conclusion (Miles, Hubermen, \& Saldana, 2013). At the reduction stage, we classified students' answers based on mathematization stages, then identified mathematics connections. Coding was made by marking each information at the problem-solving stage based on students' answers that show the understanding connection (UC), representation connection (RC), and justification connection (JC) to help make conclusions. Data was presented in a table and screenshots of students' works referring to the category of mathematics connection (Suominen, 2015), namely: (1) Understanding connection; the students identify and represent mathematical concepts through the cultural products at the stage of a concrete model; (2) Representation connection; the students show the connection between mathematical concepts and cultural products at the stage of formal model; and (3) Justification connections; the students show the representation of mathematical concepts through the model of cultural products at the formal mathematical stage. The conclusion of students' mathematics connection was drawn by analyzing the different forms of students' answers, the sequence or the suitability of the representation used to solve the problems in the test, and the students' obstacles in solving the problems based on the mathematization stages.

\section{Findings and Discussion}

The students' works on each problem of the test are presented in Table 1 and Table 2. The category of students' mathematics connection is shown in Table 3.

Table 1. Test results for the first question

\begin{tabular}{lcccc}
\hline \multirow{2}{*}{$\begin{array}{c}\text { Mathematization } \\
\text { stages }\end{array}$} & \multicolumn{2}{c}{ Students' correct answers } & \multicolumn{2}{c}{ Students' incorrect answers } \\
\cline { 2 - 5 } & $\begin{array}{c}\text { Number of } \\
\text { students }\end{array}$ & Percentage (\%) & $\begin{array}{c}\text { Number of } \\
\text { students }\end{array}$ & $\begin{array}{c}\text { Percentage (\%) } \\
\text { Identification of }\end{array}$ \\
$\begin{array}{l}\text { mathematical } \\
\text { objects }\end{array}$ & & 95,61 & 15 & 4,39 \\
$\begin{array}{l}\text { Concrete model } \\
\text { Formal model }\end{array}$ & 262 & & & \\
$\begin{array}{l}\text { Formal } \\
\text { mathematics }\end{array}$ & 257 & 76,83 & 79 & 23,17 \\
\hline
\end{tabular}


Table 2. Test results for the second question

\begin{tabular}{|c|c|c|c|c|}
\hline \multirow{2}{*}{$\begin{array}{c}\text { Mathematization } \\
\text { stages }\end{array}$} & \multicolumn{2}{|c|}{ Students' correct answers } & \multicolumn{2}{|c|}{ Students' incorrect answers } \\
\hline & $\begin{array}{c}\text { Number of } \\
\text { students }\end{array}$ & Percentage $(\%)$ & $\begin{array}{c}\text { Number of } \\
\text { students }\end{array}$ & Percentage $(\%)$ \\
\hline $\begin{array}{l}\text { Identification of } \\
\text { mathematical } \\
\text { objects }\end{array}$ & 326 & 95,61 & 15 & 4,39 \\
\hline Concrete model & 272 & 79,77 & 69 & 20,23 \\
\hline Formal model & 267 & 78,30 & 74 & 21,70 \\
\hline $\begin{array}{l}\text { Formal } \\
\text { mathematics }\end{array}$ & 252 & 73,91 & 89 & 26,09 \\
\hline
\end{tabular}

Table 3. Students' mathematics connection

\begin{tabular}{ccccccc}
\hline Question & \multicolumn{5}{c}{ Mathematics connection } \\
\cline { 2 - 7 } & \multicolumn{2}{c}{ Understanding } & \multicolumn{2}{c}{ Understanding and } & \multicolumn{2}{c}{ Understanding, representation, and } \\
& & & \multicolumn{2}{c}{ representation } & \multicolumn{3}{c}{ justification } \\
1 & 262 & $76,83 \%$ & 257 & $75,37 \%$ & 248 & $82,73 \%$ \\
2 & 272 & $79,77 \%$ & 267 & $78,30 \%$ & 252 & $73,91 \%$ \\
\hline
\end{tabular}

\section{Understanding connection}

Students' work (Figure 1) shows that students could identify cultural objects (parane ${ }^{16}$ and caraken $^{7}$ ) used to represent the fraction concept in the problem initially. An octagonal with a straight line connecting each corresponding angle and a rhombus with two straight lines connecting the parallel sides are made to follow the original shape of cultural objects at the concrete model stage. The octahedron and rhombus with connecting lines represent the concept of division in the unit form. The representations made by students in the concrete stage show that students understand the mathematical concept contained in the problem is a fraction, even though they do not represent the problem to be worked on. The examples of work that show students' correct answers only up to the concrete model stage and understand connection are presented in Figure 1.
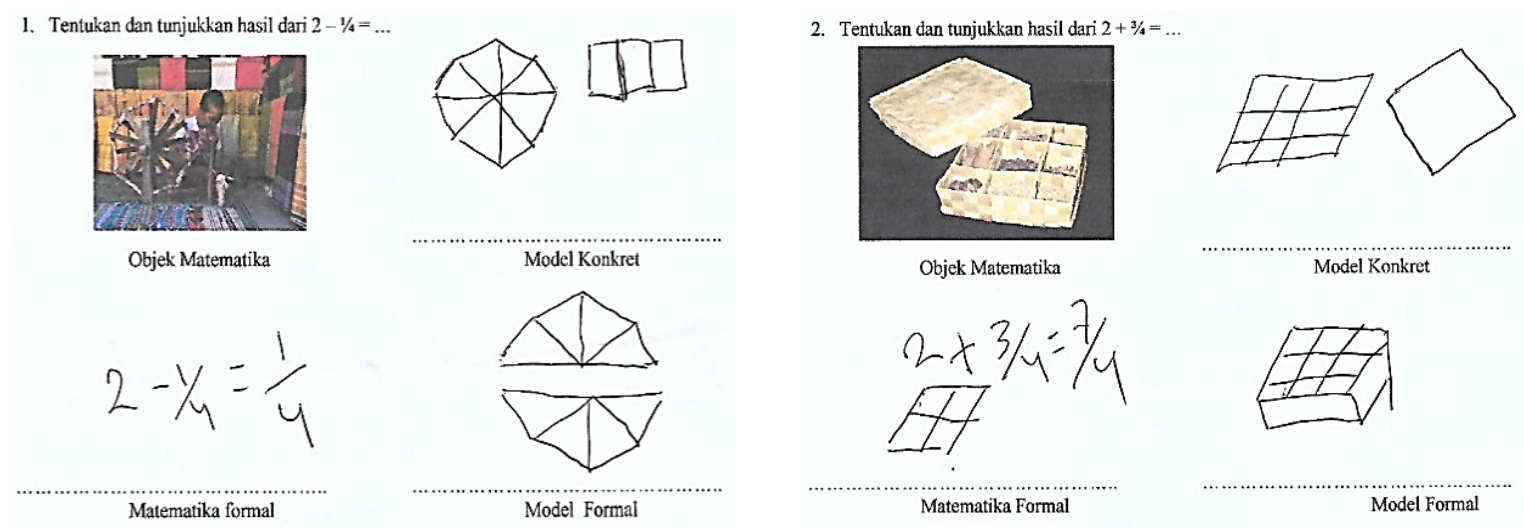

Figure 1. The students' work in the stage of the concrete model

\footnotetext{
${ }^{6}$ It is yarn spinner used for weaving by Sasak people

${ }^{7}$ It is a kitchen utensil used as cooking spices
} 
The students who answered correctly up to the stage of the concrete model are categorized as having an understanding connection since they could represent the mathematical concepts in the problem. It is shown by the ability of students to determine the focus of mathematical objects contained in the Sasak cultural product and represent the concept of fractions through octagonal and rhombus with a dividing line.

The form of representation in a concrete model should be the initial guide in representing the fractions in the test. The representation at the stage of the formal model no longer has to be the same as the original form, but rather it is adjusted to the problem (RC). The work of students in Figure 1 shows the incorrect answer because, at the stage of the formal model and formal mathematics, the drawings made do not represent the fractions in the problem.

\section{Representation connection}

The work of students in Figure 2 shows that they could identify the focus of cultural objects (parane' and caraken) to represent the fractions and modify the second drawing at the stage of the formal model. The modifications made at the formal model stage are two octagons in which one is in intact form, and another is in a separate form divided into four parts. The drawings at the stage of the formal model represent 2 and $1 / 4$ on the first problem. In problem 2, two rhombuses represent 2 and a rhombus which is divided into four by shading three of its part represent $3 / 4$. The drawings at the formal model stage show the ability of students to represent fractions in the different forms (RC). The student's correct answer up to the formal model stage is shown in Figure 2.

The students who could answer correctly up to the stage of the formal model are categorized as having an understanding connection and representation connection. It is proved by octagon and rhombus drawn based on the form of the cultural product in the problem with a dividing line. This reveals that students can identify the mathematical concepts (fractions) in the problem (UC) and modification of the drawings at the formal model stage, which represent different forms of fractions (RC). The second drawings will help students justify the answer to the problem (JC).
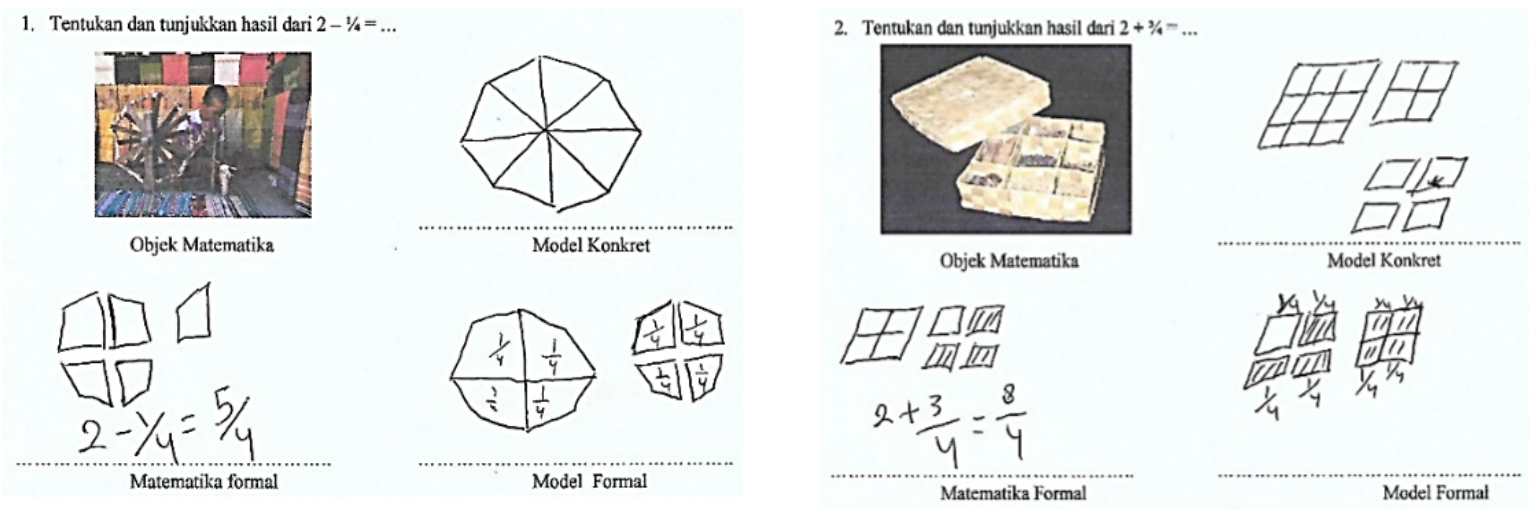

Figure 2. The students' work in the stage of the formal model

\section{Justification connection}

The work of students in Figure 3 shows that they have three mathematics connections, namely understanding, representation, and justification. It is shown by making octagonal and rhombus while still providing a dividing line that marks the concept of fractions (UC), drawings at the formal stage that represent different forms of 2 and $1 / 4$ (RC), and in the formal 
mathematical stage, the drawings made are two octagons made separately into four parts to represent 2 and $1 / 4$, one part of the drawings is shaded to show a subtraction with $1 / 4$. Thus, the drawings made at the formal mathematical model stage can be used to prove the results of 2 $1 / 4$ through the number of parts of two non-shaded octagons (JC). The correct students' work in three stages of the mathematization is shown in Figure 3.
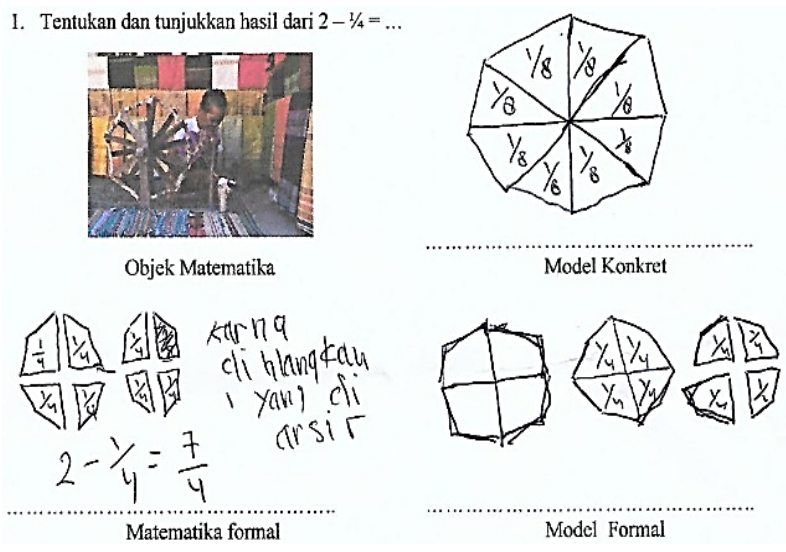

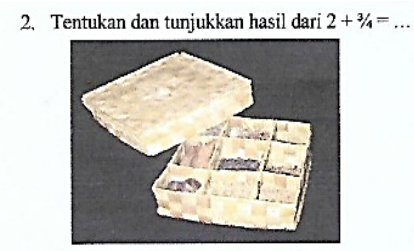

Objek Matematika

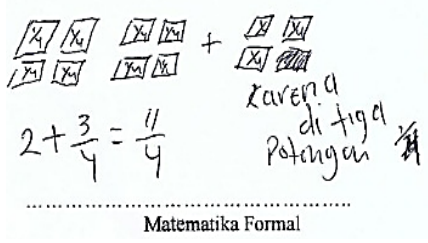

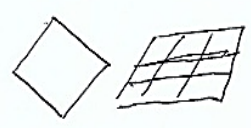

Model Konkret

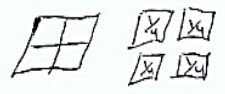
[x]

Figure 3. The students' work in the stage of formal mathematics

The work of students in Figure 3 shows that the students have three categories of mathematics connection. It is identified through the octagon and rhombus which follow the original form of Sasak cultural products at the concrete model stage (UC) with a dividing line as the concept of fractions, represent the mathematical concept in different forms that correspond to 2 and $1 / 4$ at the stage of the formal model (RC), and make different forms of representations of a similar mathematics concept in the problem or justification to the results of problem-solving (JC). On the other words, the students who have three connections are able to identify the focus of cultural objects and use it to initially represent mathematical concepts in accordance with the information in the test (UC), modify the initial representations in concrete model and relate it to mathematical concepts in the problem (RC), and make a representation which prove or justify the results of problem-solving (JC).

The learning of mathematics based on Sasak culture through problem-solving activities following mathematization can support the students to construct an understanding of real objects. The construction of understanding is done through the process of thinking following the problem-solving procedure to connect real objects that are sourced from cultural products with mathematical forms, which is by representing mathematical concepts at each stage of mathematization. The thinking process of finding new ways or ideas that help students connect various concepts and solve mathematical problems is mathematics connection (Businskas, 2008; Singletary, 2012) or relate one concept with other mathematics concepts or in the form of nonmathematical concepts (Singletary, 2012).

The differences in students' mathematics connection were then investigated through interviews. It was conducted to find out the constraints found in solving the test following the mathematization stages. The problem found in students who only completed concrete model is shown in the excerpt of the interview below. The interview shows that when continuing in the formal model, the students did not know what would be done and how the representations would be made. The students draw just like that so that each stage has an answer. 
$\mathrm{R} \quad$ : Why can't you make a representation of problem-solving from the initial drawing in a concrete model (UC)?

$\mathrm{S} 1 \quad$ : I am confused sir, because the question is a fraction, while the drawing I made is different

S2 : I don't know how to do it, because what I drew was a plane

$\mathrm{S} 3$ : I can't, sir because the fraction I remember is different from the way it was written

$\mathrm{R} \quad$ : What difficulties did you find?

S1 : Represent a fraction from the drawing I made

S2 : I am confused sir because the problem is solving fractions

S3 : I remember that the fraction has a denominator and a numerator, if I make it with a drawing, I am afraid of being wrong and I don't know how

The students who can complete up to the stage of the formal model or students who have understanding and representation connections are fixated on the number of cultural products and do not make additional drawings in order to fulfill the problems. Thus, at the formal mathematics stage, the drawings do not represent mathematical concepts in the problem.

$\mathrm{R} \quad$ : Can you represent the mathematical concepts in the problem (RC)?

S4 : Yes sir, make a drawing that shows fractions

S5 : I can sir, the drawing was partitioned

S6 : Yes sir, solving the fractions

$\mathrm{R} \quad$ : What obstacles have you found to relate the fractions with the drawing?

$\mathrm{S} 4$ : There is only one that can be used to represent fractions, not the same as the problem.

S5 : I don't think I can modify the initial drawing I made

S6 : Worried about the wrong drawing sir, so I immediately made it in the form of ordinary fractions

In general, the students still experience problems with understanding connection while it is important in determining the focus of mathematical concepts be represented. It is because of one form of the cultural product allows being used to develop various mathematical concepts. The importance of mathematics connections reveals that mathematics is not a rigid or static science and considered to have no relationship with daily life (Johnson \& Litynsky, 1995). These conditions will affect the meaningfulness of mathematics learning.

Students' attempt to connect mathematics is certainly not an easy task. The constraints are not only found in students who do not have all three categories of mathematics connection but also by students who complete the problem in all stages. It is indicated by the excerpts of interviews below.

$\mathrm{R} \quad$ : What are the obstacles you face in answering questions following the stages of mathematization?

$\mathrm{S} 7 \quad$ : Sometimes it is doubtful to choose the object to be focused on to represent mathematical concepts

S8 : Do not directly make a drawing sir, I need a trial error

S9 : Understand the information in the problem and determine what will be used in drawing

$\mathrm{R} \quad$ : What did you do to resolve the issue and believe the answer was correct?

$\mathrm{S} 7$ : Comparing some drawings. Which one is felt most appropriate then use it to answer the problem

S8 : Try all drawings that can be made before they are set as the answer 
The obstacles that affect students' mathematics connections above are interesting to note for further study because culture-based mathematics learning as part of constructivist learning expects students to participate in the learning actively and construct their understanding. These goals will be obstructed if the conditions and habits of students in learning lack relevant to the desired ideal conditions. Thus, mathematics teachers are always expected to familiarize students with constructing understanding in developing their mathematics connection or make the adjustment so that ethnomathematics is applicable.

Based on the students' work on the test, the characteristics of student answers at the stage of a concrete model is making a drawing that represents the concept of fraction relating to the cultural object. The drawing made only to show the mathematical concepts in the problem and have not shown its value. It is important to ensure that students understand the mathematical concepts in the problem to be worked on. At the formal model stage, drawings made to represent the value of numbers (fractions) in the problem. In the formal mathematics stage, drawings are made to represent evidence of solving the problem. Understanding connection shows the ability of students to understand the mathematical concepts in the problem. Representation connection reveals the ability of students to make different forms of the concept of fractions in the problem. Justification connection indicates the ability of students to prove in different representations of problem-solving.

The three categories of mathematics connection are applied sequentially in problem-solving following the mathematization stage. The students must have all three connections to solve problems correctly at each stage. The understanding connection is needed to make representations at the concrete model stage, representation connection is required to make representations at the formal model stage, and justification connection is demanded to make representations at the formal mathematical stage. Based on the stages of problem-solving, the three categories of mathematical connection are needed sequentially in solving problems in learning mathematics based on Sasak culture.

Referring to the identification of mathematics connection at each stage of problem-solving, mathematics learning by utilizing cultural products has the potential as an alternative to develop students' mathematics connection. That is because learning mathematics that utilizes contextual objects or related to real-life can be used to develop students' mathematical connection as shown by related studies (e.g., Jaisook et al., 2013). However, the current study cannot be used as a basis for stating that culture-based learning supports students' mathematics connection abilities; thus, further research is required.

\section{Conclusion}

This study identified students' mathematics connections in solving mathematics problems after participating in culture-based mathematics learning, namely understanding connection, representation connection, and justification connection. The three categories of connections are shown respectively at the stage of the concrete model, formal model, and formal mathematics as the mathematization stages. The mathematics connections are a hierarchy in problem-solving through the mathematization. Each stage of problem-solving is inseparable from the previous stage, representations at the concrete model stage help students make another representation at the formal model stage, and so is in the formal model and formal mathematics stage. Thus, the 
mathematics connection to make a representation at each stage also supports the student's ability to solve problems at the whole step of the mathematization sequentially. Although there are still problems associated with students' understanding of the different forms of a mathematical concept, culture-based mathematics learning offers an opportunity to understand students' mathematics connection and alternative to develop students' mathematics connection which is required to be further studied.

\section{Reference}

Arthur, Y. D., Asiedu-Addo, S., \& Assuah, C. (2017). Connecting mathematics to real life problem using instructor quality and availability, mathematics facility and teacher motivation for prediction. International Journal of Scientific Research in Education, 10(3), 311-324.

Boswinkel, N., \& Moerlands, F. (2003). Het topje van de ijsberg (The top of the iceberg). In De Nationale Rekendagen, een praktische terugblik (National conference on arithmetic, a practical view). Utrecht: Freudenthal Institute.

Brownell, W., \& Chazal, C. (1935). The effects of premature drill in third-grade arithmetic. Journal of Educational Research, 29, 17-28.

Businskas, A.M. (2008). Conversations about connections: How secondary mathematics teachers conceptualize and contend with mathematical connections (Doctoral dissertation, Simon Fraser University, Canada). Retrieved from https://core.ac.uk/download/pdf/56373465.pdf

Chahine, I., \& Kinuthia, W. (2013). Juxtaposing form, function, and social symbolism: An ethnomathematical analysis of indigenous technologies in the Zulu culture. Journal of Mathematics \& Culture, 7(1), 1-30.

Coxford, A.F. (1995). The case for connections. In P.A. House \& A.F. Coxford (Eds.), Connecting mathematics across the curriculum (pp. 3-12). Reston, VA: NCTM.

Cresswell. (2015). Planning, conducting, and evaluating quantitave and qualitative research. Universty of Nebraska-Lincoln: Pearson.

Ernest, P. (1991). The philosophy of mathematics education. London: Falmer Press.

Haji, S., Abdullah, M. I., Maizora, S., \& Yumiati, Y. (2017). Developing students'ability of mathematical connection through using outdoor mathematics learning. Infinity Journal, 6(1), 11-20.

Hiebert, J.,\& Carpenter, T. P. (1992). Learning and teaching with understanding. In D. A.Grouws (Ed.), Handbook of research on mathematics teaching and learning (pp. 127-146). New York: Macmillan.

Hodgson, T.R. (1995). Connections as problem-solving tools. In P. A. House \& A. F. Coxford (Eds.), Connecting mathematics across the curriculum (pp. 13-21). Reston, VA: NCTM.

Jaisook, S., Chitmongko, S., \& Thongthew, S. (2013). A mathematics instructional model by integrating problem-based learning and collaborative learning approaches. Journal of Social Sciences, Humanities, and Arts, 13(2), 271-294.

Johnson, A. (2010). Teaching mathematics to culturally and linguistically diverse learners. Boston, MA: Pearson Education

Johnson, K.M., \& Litynsky, C.L. (1995). Breathing life into mathematics. In P. A. House \& A. F. Coxford (Eds.), Connecting mathematics across the curriculum (pp. 225-232). Reston, VA: NCTM.

Katsap, A., \& Fredrick, A.L. (2008). Case study of the role of ethnomathematics among teacher education students from. The Journal of Mathematics and Culture, 3(1). 1558-5336.

Lappan, G., Fey, .J.T., Fitsgerald, W.M., Friel, S.N., \& Philips, E.D. (2002). Getting to know connected mathematics: An implementation Guide. New Jerssey: Prentice Hall.

Menanti, H., Sinaga, B., \& Hasratuddin. (2018). Improve mathematical connections skills with, realistic mathematics education based learning. Advances in Social Science, Education and Humanities Research, 200, 29-35.

Miles, M.B., Hubermen, A.M., \& Saldana, J. (2013). Qualitative data analysis: A methods sourcebook. London: Sage Publication

NCTM. (2000). Principles and standards for school mathematics. Reston, VA: NCTM. 
Ndiung, S., \& Nendi, F. (2017). Mathematics connection ability and students mathematics learning achievement at elementary school. Retrieved from http://www.shsconferences.org/articles/shsconf/pdf/2018/03/shsconf_gctale2018_00009.pdf

Rohendi. D, J., \& Dulpaja. (2013). Connected Mathematics Project (CMP) model based on presentation media to the mathematical connection ability of junior high school student. Journal of Education and Practice. 4(4), 17-22.

Sharp, J., \& Stevens, A. (2007). Culturally-relevant algebra teaching: The case of African drumming. The Journal of Mathematics and Culture, 2(1), 37-57.

Singletary, L.M. (2012). Mathematical connections made in practice: An examination of teachers' beliefs and practices (Doctoral dissertation, University of Georgia, Athens, GA). Retrieved from https://getd.libs.uga.edu/pdfs/singletary_laura_m_201208_phd.pdf

Skemp, R.R. (1987). The psychology of learning mathematics. Harmondsworth, England: Penguin.

Suominen, L.A. (2015). Abstract algebra and secondary school mathematics: Identifying and classifying mathematical connections (Doctoral dissertation, University of Georgia, Athens, GA). Retrieved from https://getd.libs.uga.edu/pdfs/suominen_ashley_1201505_phd.pdf

Unodiaku, S. S. (2013). Effect of ethno-mathematics teaching materials on students' achievement in mathematics in Enugu State. Journal of Education and Practice, 4(23), 70-77.

Webb, D. C., Boswinkel, N., \& Dekker, T. (2008). Beneath the tip of the iceberg: Using representations to support student understanding. Mathematics Teaching in the Middle School, 14(2), 110-113.

Yusuf, M. W., Ibrahim Saidu, I., \& Halliru, A. (2010). Ethnomathematics (A mathematical game in Hausa culture). International Journal of Mathematical Science Education, 3(1), 36-42. 